\title{
The Research of "TCSA" Teaching Model in the Course of Marketing Peng $\mathrm{An}^{1, \mathrm{a}}$ and Hongying $\mathrm{Ji}^{2,} \mathrm{~b}^{*}$ \\ ${ }^{1,2}$ School of Economics and Management, Beihua University, China a562402198@qq.com, ${ }^{\mathrm{b}} 418470072 @ q q . c o m$ \\ * please mark the corresponding author with an asterisk
}

\section{Keywords: Marketing; TCSA; Teaching model}

\begin{abstract}
With the development of social economy and demand for higher talents, the requirement about society for marketing professional talent has been higher and systematic. Nowadays, more and more enterprises tend to not only understand marketing personnel master of marketing knowledge, but also learn to how to apply the theoretical knowledge to practice. "TCSA" teaching mode by integrating theory with practice teaching method can be better to let the student understand the theoretical knowledge through the form such as case teaching, simulation teaching into practice. This paper, taking the curriculum as an example, the marketing management discipline in the years of teaching practice, researches the "TCSA" teaching model in the marketing course, the construction of a comprehensive teaching mode, and discusses its effect in the practice of teaching.
\end{abstract}

\section{Introduction}

For many years teaching Chinese scholars, university teachers and students have been discussed how to elevate the teaching quality of higher education a new height. In the past years of teaching practice, higher education has been thinking about how to apply the teaching idea of development to the best state, will to participate in the practice of theory is feasible [1]. By constantly reforming teaching mode and the management class talented person's demand characteristics, "TCSA" four integrated teaching mode can effectively for the curriculum teaching reform of marketing to provide a relatively good quality new mode of teaching.

\section{The Nature and Characteristics of the "Marketing" Course}

"Marketing" in the beginning of the 20th century in American society, and the marketing theory are introduced into China in 1978. In system development and reform and development under the background of market economy, the modern marketing theory in the rapid development of our country. "The course of Marketing " is a manager based on science, behavior science and management science and so on many scientific course of applied science, on the basis of its value both in theory and also attaches great importance to the strategy research and practical application [2]. In the modern market economy environment, principles of marketing is not only applied in enterprises, government and non-profit organization, and gradually turned to the application in the macro, meso and micro three levels, involves the social and economic aspects. Marketing is not the management, financial and other professional required course, but also the importance of humanities, philosophy and social sciences and other professional courses.

\section{The Social Requirement for Marketing}

Nowadays, the society from all walks of life in the process of self development is inseparable from the marketing personnel, for each individual or enterprise wants to know enterprise development market, how to seize the opportunity, how to develop good products to sell in the market, how to make feasible marketing strategy, how to make reasonable sales and reduce cost [3]. This a series of problems will bring all kinds of difficulties, and then every enterprise want to spend a high salary to hire marketing expert to 
business guidance. Many enterprises gradually focused on marketing talents, it is confirmed today the most popular of popular management disciplines, the phenomenon of "marketing" has been high.

Most enterprises treat marketing talents mainly for the marketing planning, market research, market development, advertisement plan, product sales, etc. Enterprise for both primary marketing talent and senior marketing personnel are still having a large demand. And "marketing" course is the professional ability of economic management class students to master the required course, and many other professional courses of students. In the course of teaching, the students can fully understand the enterprise needs the knowledge of marketing talents.

In addition, enterprises for marketing researchers pay more attention to the comprehensive ability and quality, including marketing, professional ability, social adaptation ability and social communication method, practice your ability is a unit of choose and employ persons in society for marketing major student to ask for one of the most basic. However, during the period of school students are basically less theoretical knowledge, practice, it is difficult to meet the requirements of combining theory with practice, the students lack of practical skills and the ability to improvise.

\section{The Curriculum Teaching Present Situation of the "Marketing" Course}

In recent years, "Marketing" teaching mode of university mainly based on the traditional teaching mode, which used to focus on book knowledge learning and accumulation, with the teacher in the lecture hall to mechanical way of education for the students. And this kind of teaching mode is too "cramming" teaching. In the domestic teaching process, the common problems are the following:

First, most based on teachers' teaching activities, teaching knowledge most classroom learning is given priority to, also do not let the student to carry on the discretionary time to carry out the marketing direction of curriculum knowledge. Second, the classroom was telling marketing point of view, most by the teacher's marketing thinking instead of students' thinking, did not achieve much thinking communication between each other; Teaching methods with only books as a center, social economic development and the reality, and other disciplines applications contact less, teaching content is too close and doesn't have strong practice ability; How to cultivate students' innovation spirit and didn't pay attention to, while the teaching mode in the teaching process of using case study, but the application cases of the overwhelming majority of successful in today's society and the public's case as the main material is analyzed, and the material is not able to bring substantial marketing quality promotion for students.

"Marketing" of the university course at the beginning of the construction course, separating the theory course and practice course, make sure you are able to let the students hands-on practice opportunities, such as market research for business class practice base design planning, marketing planning, sales promotion, etc. But due to the marketing of the course in colleges and universities only for individual professional courses in practice activities, business class, time is too tight and not to make the students improve marketing ability of practice. Serious disconnect between theory and practice of the phenomenon, the need to "marketing" course hair how to upgrade to the original teaching mode optimization, apply students' innovation spirit and practice ability, strain expression ability better cultivated in the curriculum become particularly important.

\section{Direction "Marketing" Course Teaching Mode}

"Marketing" is a typical applied course and the purpose is that students can learn by this course of access to basic application ability, reliable practical experience. Based on the nature and characteristics of the course in colleges and universities on the basis of the "marketing" course teaching mode scheme in modern higher education thought and education target direction as the main starting point, to cultivate students with the theoretical consciousness of the market, a clear direction, teaching mode and application "TCSA" teaching model as the carrier, to arouse the students' autonomy, enthusiasm and creativity.

Imparting the Relationship Between Knowledge and Cultivating Students' Ability. In previous teaching reform practice, the marketing course is not too concerned about the relationship between imparting knowledge and cultivating students' ability. From the direction of talent training, the whole 
process of teaching interaction will need to impart knowledge and cultivate students' ability of mixture of thought, combine to "passive learning", "keep learning" into "active learning", "innovative learning", the students learn the theoretical knowledge into their own professional ability of students. The need for "marketing" course in colleges and universities of its own resources to change just to teach instead of defects of cultivating the ability of students.

Intensifying the Application of Teaching. "Marketing" curriculum content of teaching should pay attention to the student application ability raise. According to the principle of "knowledge", in the teaching, should weaken the written content of theoretical knowledge, strengthening the practice of the application of content, pay attention to cultivate students' concept of marketing thinking ability, practical abilities and so on to analyze and solve problems.

Pay Attention to the Multidisciplinary Combination Optimization Combination mode. "Marketing" has great reference value for various fields. Mastering the development reality of the marketing economic environment at home and abroad, combines courses in marketing and other fields, to drive students to study more deep thinking and cultivate students' innovation. North university of China, except for the curriculum teaching of marketing also extends the "international marketing", the "tourism marketing" and other courses, more comprehensive combination optimization between disciplines, and enables students to better develop their own characteristics in this kind of education mode.

\section{The Structure of "TCSA" Teaching Mode}

Marketing, as an established in many fields of applied science, it has to do with society and people's lives are closely related. Meanwhile it focuses on the concept of combining theory and practice to focus on production and openness. "Marketing" most of the content of curriculum has social universal, such as market positioning, product pricing, promotion, promotion; channel construction work can be from a different Angle [3]. So how to better the marketing from theory improve applied course, in the process of curriculum design and teaching organization, build "TCSA" four integrated teaching mode, namely the Theoretical Teaching- Case Teaching - Situational Teaching- Actual Teaching.

Theoretical Teaching. Theory teaching is a kind of traditional teaching methods, even to text, but the theoretical teaching is always an important and indispensable link of the teaching process. "Marketing" course in colleges and universities shall specify the knowledge content of the main system. Course is mainly to introduce students to the basic concept of the marketing and the basic theory, deep marketing knowledge to lay a solid foundation for further research. Generally speaking, the curriculum in four major areas of marketing overview to teach students about marketing, marketing analysis, marketing strategy, marketing strategy [3]. In addition, the curriculum teaching of marketing books by each college economic management college marketing professional teachers compilation, it can adapt to college students master the theoretical knowledge. At the same time, prepare delicate electronic courseware teaching, according to the teaching outline the main content of the professor will make full use of the electronic multimedia devices provide students with the application of enough information.

Case Teaching. Case teaching in various fields is typical of teaching methods, and among the management discipline, case teaching business management teaching by reference to the undergraduate course teaching and formed a relatively mature marketing methods.

First of all, "marketing" course in colleges and universities in the compilation of teaching materials, and design electronic courseware, interspersed with many related to the corresponding section of case study section. Application cases in the form of asked the students to better understand the reality of analysis to discuss the concept and theory, and thus deepen students' understanding of knowledge; Secondly, after the end of each chapter to teach, students are required to check in their spare time on the social and knowledge corresponding to the actual case, the form of group team thinking and discussion, deepen students' understanding of knowledge and teachers to master degree students to master knowledge. By way of case teaching, can let the students know about marketing activities have a certain colleague, also can strengthen students' ability to apply knowledge of comprehensive analysis of management, form a good interaction between teaching.

Situational Teaching. Situational teaching is a kind of participatory teaching method; it is with the aid 
of environment, the roles and activities of simulation to help students to understand the market marketing professional theory knowledge, and master appropriate methods of marketing management [4]. At the same time, it also can stimulate students' thinking and cultivate their creative thinking and ability to cooperate. Simulation teaching mainly is to let the students act as the molecules of marketing activities (i.e., the role of marketing members), to stimulate their autonomy, enthusiasm, thus forming a kind of experiential teaching methods. In it to make them understand mutual combination of theory and practice, between feeling and scene to connect, team cooperation tacit understanding and effective knowledge and interest combined with each other as the show in Table 1.

Table 1 The basic procedure of TCSA simulation teaching method

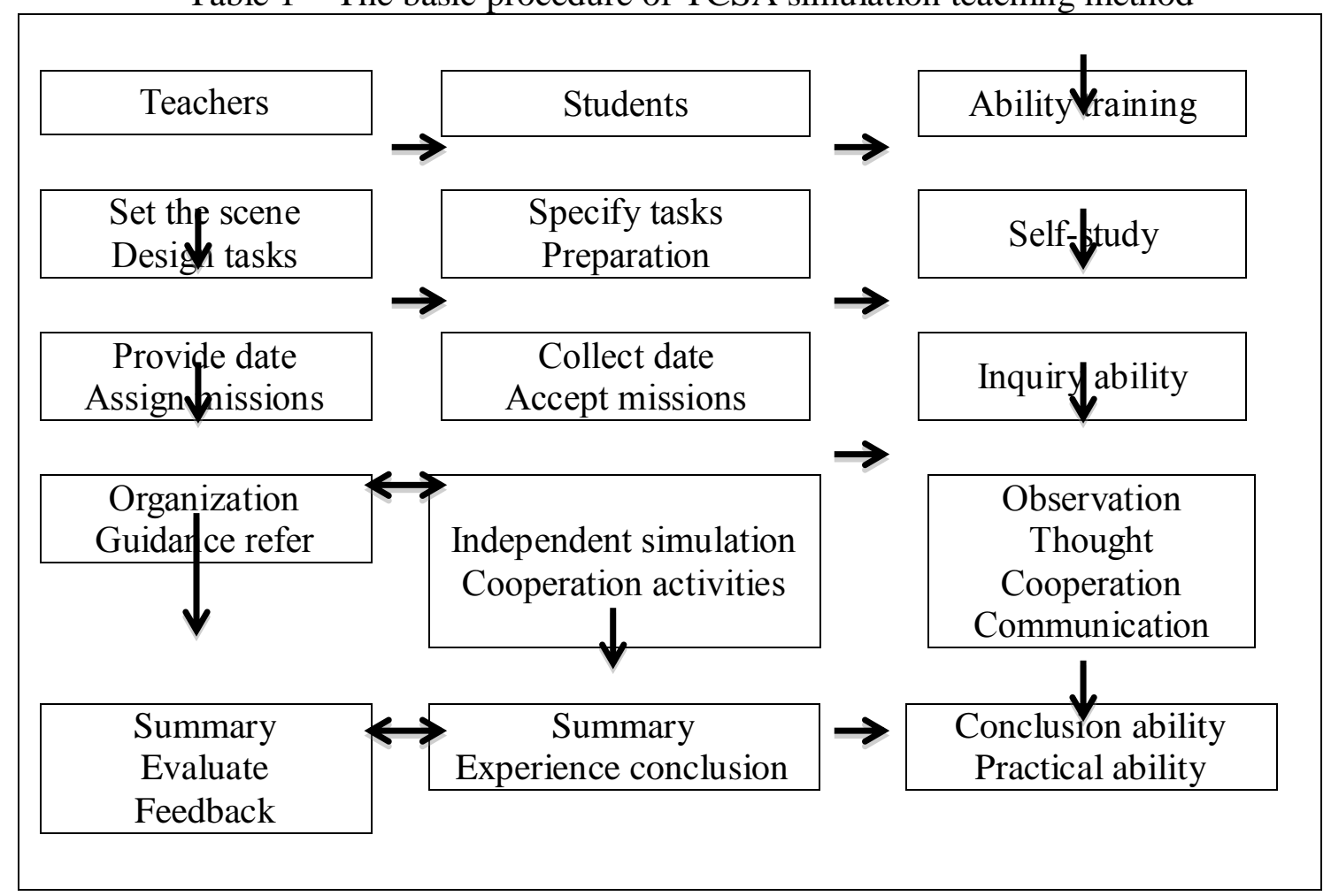

Actual Teaching. Actual teaching is the use of university-enterprise cooperation between entrepreneurship for college students to provide the corresponding innovation place, guide students to engage in specific market development, marketing planning, commodity procurement management interaction. Of university in the annual contest of college students' innovative entrepreneurial activity, studied the marketing course of the students as the important member of the team, make innovations in entrepreneurial activities in multiple field and market investigation, and use their spare time to carry out marketing activities, from activity will theory is applied to the social practice, to make it better into their own capabilities. In institutions of higher learning in the market practice, such as combined with ERP sand table simulation experiment courses, teaching and other professional students with the principle of complementary advantages, actual combat team, under the guidance of full-time teachers, team to learn the basic knowledge of applied to the market actual combat each link. At the same time, with the help of school provide all aspects of the platform, the teams to actively participate in national level between colleges and universities in the competition of the among each practical teaching, give full play to their respective jobs. At the end, the practical teaching forms a team of actual combat and the end of the communication. To ensure that learn to experience.

\section{Summary}

Above all, to build "TCSA" teaching model to the students' interest and knowledge also got fully extended, as well as the marketing courses teaching in the process of development in the future, provides 
valuable advice.

\section{Acknowledgements}

The authors thank for the support according to the teaching research project of youth from Beihua University - the construction and implement of the "marketing" course by the TCSA four integrated teaching mode, as an example by the Beihua University (No. XJQN2016029).

\section{Reference}

[1] Tang Yusheng, Liang Yan. An Empirical Study on the integration of teaching content and teaching method in marketing [J]. Journal of Nanchang Aeronautical University: Social Science Edition, 2007 (10).

[2] Song $\mathrm{Yu}$, Wang Kezhu. Research on $\mathrm{J}$ mode of cultivating application-oriented marketing professional "3+1" talents. Heilongjiang higher education research, 2010 (1).

[3] Hong Yanyun, Li Nan. Construction and implementation of "four in one" teaching model of marketing TCSA. [J]. Journal of Jiangsu Teachers University of Technology, 2010, (02): 71-75.

[4] Li Xiaozhong, Yu Xiaonuo, Tang Jianrong. Exploration of collaborative training mode of innovative talents in economics and management class [J]. China off campus education, 2013, (7): 46-46 